\title{
Spinel-Bearing Lherzolite Xenoliths from Hosséré Garba (Likok, Adamawa-Cameroon): Mineral Compositions and Geothermobarometric Implications
}

\author{
Nguihdama Dagwai', Chazot Gilles², Kamgang Pierre³, Mbowou Gbambié Isaac Bertrand", \\ Ngounouno Ismaïla 4 \\ ${ }^{1}$ Ecole Normale Supérieure, Université de Maroua, Maroua, Cameroun \\ ${ }^{2}$ Université Européenne de Bretagne, Brest, France \\ ${ }^{3}$ Département des sciences de la Terre, Faculté de Sciences, Université de Yaoundé I, Yaoundé, Cameroun \\ ${ }^{4}$ Ecole de Géologie et d'Exploitation Minière (EGEM), Département de Mines et de la Géologie, Université de \\ Ngaoundéré, Meiganga, Cameroun \\ Email: da nguihdama76@yahoo.fr
}

Received 9 September 2014; revised 5 October 2014; accepted 2 November 2014

Copyright (C) 2014 by authors and Scientific Research Publishing Inc.

This work is licensed under the Creative Commons Attribution International License (CC BY).

http://creativecommons.org/licenses/by/4.0/

cc) (i) Open Access

\section{Abstract}

Spinel-bearing lherzolite xenoliths from the Hosséré Garba (1272 m.a.s.l) volcano on the Adamawa Plateau, is located in Likok village, at about $35 \mathrm{~km}$ to WSW of Ngaoundéré. These xenoliths ( $11 \mathrm{~cm}$ size) have been sampled into the host basaltic lava flows from the NE flank of the Hosséré Garba volcano. These xenoliths characterized by porphyroclastic texture consisted of olivine $(\sim 55$ vol.\%), orthopyroxene ( $\sim 19$ vol.\%) and clinopyroxene ( $\sim 21$ vol.\%) crystals. Spinel crystals $(\sim 5$ vol.\%) are red brown and interstitial between the crystals of olivine and pyroxenes. CaO contents are low $(<0.08 \mathrm{wt} \%)$ in olivine and similar to those estimated (CaO: $0.05-0.1 \mathrm{wt} \%)$ for the mantle origin. The values of $\mathrm{Al}^{\mathrm{VI}} / \mathrm{Al}^{\mathrm{IV}}$ ratio range between 1.1 and 1.3 for the $\mathrm{Cr}$-diopside crystals from Hosséré Garba xenoliths. The constant value of the volumes V(Cell) and V(M1) for clinopyroxene compositions, indicates the similar pressures. Hosséré Garba represents a residual sequence issued from partial melting of a mantle source. Similar compositions have been recorded in minerals of ultramafic xenoliths from other ultramafic xenoliths domains of the Cameroon Line and the Adamawa Plateau.

\section{Keywords}

Xenoliths, lherzolite, Geothermobarometry, Likok, Adamawa 


\section{Introduction}

Ultramafic xenoliths generally are considered as small parts broken or separated off the lithospheric mantle [1]; or the residues of partial melting of the upper-mantle [2] hosted in basaltic lava during volcanic eruption. These ultramafic xenoliths ejected from volcanoes at the surface, as solid fragmentary material, are important to the knowledge of the textural features, chemical evolutions, temperature and pressure conditions of the upper mantle. Upper-mantle xenoliths were found in basaltic lavas from several localities along the Cameroon Volcanic Line [3]-[5]. However, beneath the volcanoes of the Adamawa Plateau, there are few available data aside from ultramafic xenoliths described from the Dibi volcano [6] [7], Youkou maar [8] and Ngao Voglar volcano [4]. Lherzolite xenoliths described in this paper are discovered in the Hosséré Garba (1272 m.a.s.l) volcano on the Adamawa Plateau, which consist of basaltic lava flows, more or less fragmented into rounded sparse blocks. Hosséré Garba is located in Likok village, at about 35 km to WSW of Ngaoundéré (Figure 1).

In this paper, we present the first petrography and mineral chemistry of spinel-bearing lherzolite xenoliths from Hosséré Garba (Likok) in the Adamawa Plateau. Chiefly, the objective is to enhance the knowledge of upper mantle beneath the Adamawa Plateau volcanic domain.

\section{Geological Setting and Petrography}

The Adamawa Plateau is a tectono-magmatic domain, bounded respectively to the North and South by the Adamawa and Djerem-Mbéré faults, oriented N70 E [9]. The Adamawa basement rocks consist of Paleo-Proterozoic metamorphic rocks (2.1 Ga; [10] [11]), which were intensively remobilized by the Pan-African orogenesis [12]-[14]. These rocks crossed by the deformed and metamorphosed granitoids with ages of $615 \pm 27 \mathrm{Ma}$ to $575 \pm 27 \mathrm{Ma}$ [15] are partially covered by Cenozoic basaltic and felsic [16]-[20].

Spinel-bearing lherzolite xenoliths have been sampled into the basaltic lava flows from the NE flank of the Hosséré Garba volcano (Likok sector, Adamawa Plateau). These xenoliths ( 11 cm size) characterized by porphyroclastic texture [21] with a cataclastic appearance are greenish yellow and slightly dark. Olivine ( 55 vol.\%), orthopyroxene ( 19 vol.\%) and clinopyroxene ( 21 vol.\%) crystals identified in these xenoliths are more or less equigranular (up to $0.4-1 \mathrm{~cm})$. Spinel crystals ( 5 vol.\%) are red brown and interstitial between

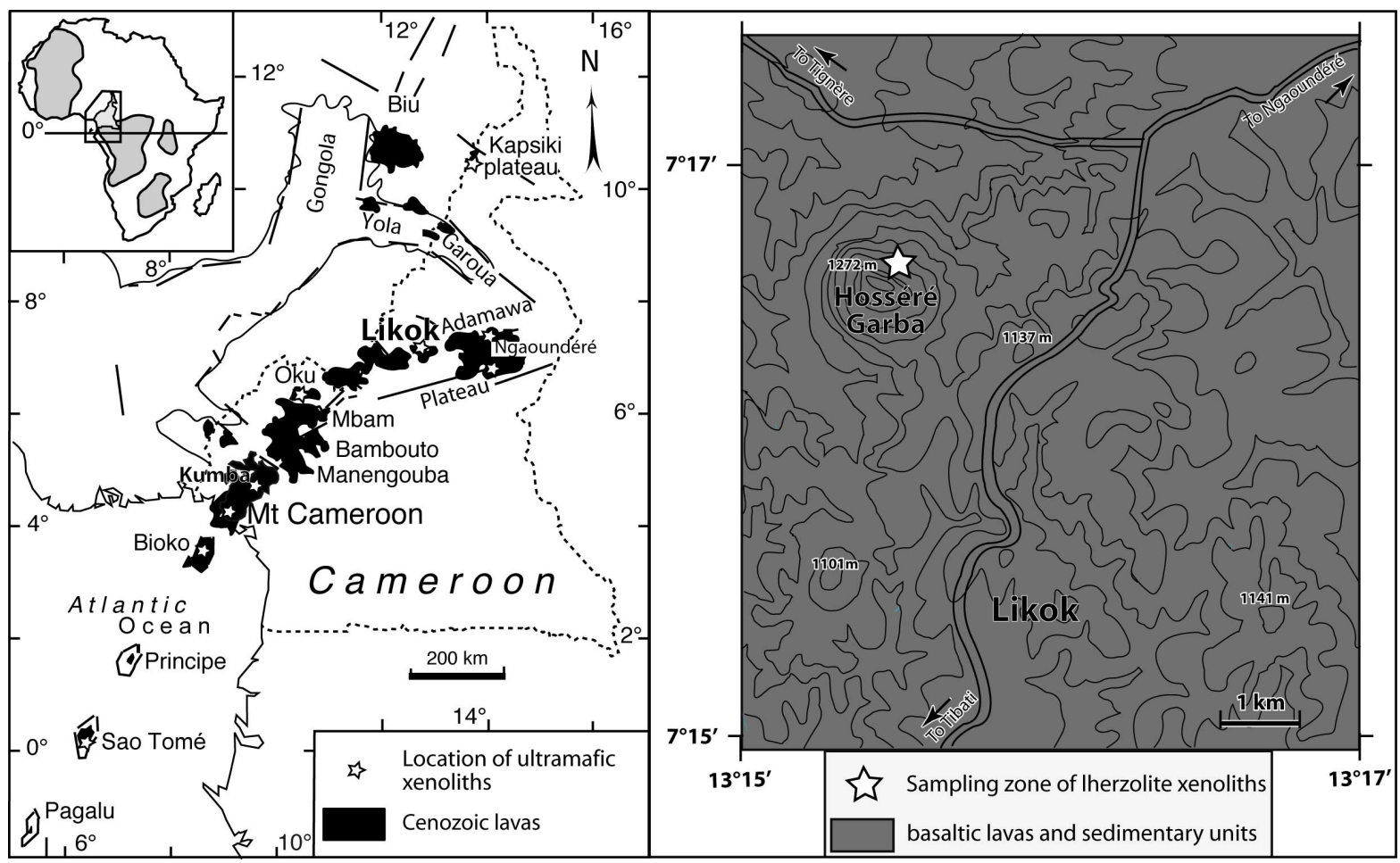

Figure 1. Location of the ultramafic xenoliths from the Hosséré Garga (Likok), and from the other sectors of the Cameroon Volcanic Line and the Adamawa Plateau. 
the crystals of olivine and pyroxenes. The "kink-bands" structure characterizes some olivine crystals. Many triple-points involving olivine, pyroxene and spinel show evidence of a particular equilibrium condition between these minerals [22]. The tiny host basalt veins are present in rim sections of the lherzolite xenoliths from Hosséré Garba.

\section{Analytical Methods}

Chemical analyzes ("Université de Bretagne Occidentale-Brest, France”) of major elements were performed using an electron microprobe with beams of: 10 and $40 \mu \mathrm{m}, 15 \mathrm{kV}$ and $15 \mathrm{nA}$. Errors considered for these analyzes are between $5 \%$ and $10 \%$ of measured values $<1 \%$ and between $1 \%$ and $5 \%$ of the measured values $>1 \%$. Measurements of trace elements of the different phases have been produced using a technique laser ablation of a mass spectrometer coupled plasma source (LA-ICP-MS). The beam size varies between 40 and $70 \mu \mathrm{m}$. Counts where repeated several time for each spot analysis and averaged. The number of repeated analyses and the duration of the counting times depend on the concentration level of the elements studied. To examine homogeneity of constituent mineral, more than seventeen crystals each of clinopyroxène were selected at random from each thin section. Calcium is used as an internal standard, while the NIST 612 is used as an external standard. The accuracy is better than $10 \%$. The whole rock analyzes were performed previously in solution using ICP-AES for major elements and ICP-MS for trace elements.

\section{Mineral Chemistry}

\subsection{Olivine}

The forsterite component of olivine range from 89 to 90 (Table 1), with the high values of Mg\# [Mg\# = $100 \times$ atomic $\left.\mathrm{Mg} /\left(\mathrm{Mg}+\mathrm{Fe}^{2+}\right)\right](89-90)$.

These values are similar to those calculated for the lherzolite xenoliths from Ngao Voglar. NiO contents reaching $0.41 \mathrm{wt} \%$ in the olivine from Hosséré Garba xenoliths. CaO contents are low ( $<0.08 \mathrm{wt} \%$ ) and similar to those estimatited (CaO: $0.05 \mathrm{wt} \%-0.1 \mathrm{wt} \%)$ by [23] for the mantle origin, which characterize equilibrium environment of high pressure (>0.2 GPa; [24]).

Table 1. Olivine compositions (wt\% and a.p.f.u. on the basis 4 oygens).

\begin{tabular}{|c|c|c|c|c|c|c|}
\hline $\mathrm{SiO}_{2}(\mathrm{wt} \%)$ & 40.96 & 41.47 & 41.05 & 41.13 & 40.93 & 40.94 \\
\hline $\mathrm{Al}_{2} \mathrm{O}_{3}$ & 0.02 & 0.02 & 0.02 & 0.05 & 0.01 & 0.01 \\
\hline $\mathrm{FeO}$ & 9.77 & 10.12 & 9.89 & 10.11 & 9.95 & 9.98 \\
\hline $\mathrm{MnO}$ & 0.16 & 0.16 & 0.12 & 0.16 & 0.12 & 0.16 \\
\hline $\mathrm{MgO}$ & 49.26 & 49.53 & 48.83 & 49.41 & 49.24 & 49.38 \\
\hline $\mathrm{CaO}$ & 0.07 & 0.05 & 0.02 & 0.06 & 0.05 & 0.01 \\
\hline $\mathrm{NiO}$ & 0.37 & 0.33 & 0.34 & 0.41 & 0.25 & 0.36 \\
\hline Sum & 100.61 & 101.68 & 100.27 & 101.33 & 100.55 & 100.84 \\
\hline Si (a.p.f.u.) & 0.998 & 1.001 & 1.004 & 0.997 & 0.999 & 0.997 \\
\hline $\mathrm{Al}$ & 0.000 & 0.000 & 0.000 & 0.001 & 0.000 & 0.000 \\
\hline $\mathrm{Fe}^{2+}$ & 0.199 & 0.204 & 0.202 & 0.205 & 0.203 & 0.203 \\
\hline $\mathrm{Mn}$ & 0.003 & 0.003 & 0.003 & 0.003 & 0.003 & 0.003 \\
\hline $\mathrm{Mg}$ & 1.790 & 1.782 & 1.780 & 1.785 & 1.791 & 1.792 \\
\hline $\mathrm{Ca}$ & 0.002 & 0.001 & 0.001 & 0.001 & 0.001 & 0.000 \\
\hline $\mathrm{Ni}$ & 0.007 & 0.006 & 0.007 & 0.008 & 0.005 & 0.007 \\
\hline $\mathrm{Fa}(\%)$ & 10.0 & 10.3 & 10.2 & 10.3 & 10.2 & 10.2 \\
\hline Fo & 90.0 & 89.7 & 89.8 & 89.7 & 89.8 & 89.8 \\
\hline
\end{tabular}




\subsection{Pyroxene}

Clinopyroxene compositions $\left(\mathrm{En}_{53.1-54.9} \mathrm{Wo}_{43.5-44.8} \mathrm{Fs}_{3.4-0.3}\right)$ fall within the diopside field, according to Wo-En-Fs diagram Figure 2 (Morimoto et al. 1988).

The $\mathrm{TiO}_{2}$ contents range from 0.42 to $0.54 \mathrm{wt} \%$ and those of $\mathrm{Al}_{2} \mathrm{O}_{3}$ from 6.5 to $6.9 \mathrm{wt} \%$ (Table 2).

These diopside crystals are $\mathrm{Cr}$-rich with the values of $\mathrm{Cr} \#[\mathrm{Cr} \#=100 \times$ atomic $\mathrm{Cr} /(\mathrm{Cr}+\mathrm{Al})](6.5-7.2)$ typical of Cr-diopside [25]. The clinopyroxene is characterized by Mg\# [Mg\# $=100 \times$ atomic $\left.\mathrm{Mg} /\left(\mathrm{Mg}+\mathrm{Fe}^{2+}\right)\right]$ values of 94.3 - 97.8, higher than those of coexisting orthopyroxene (see below) and olivine. The values of Al${ }^{\mathrm{VI}} / \mathrm{Al}^{\mathrm{IV}}$ ratio range between 1.1 and 1.3 for the Cr-diopside crystals from Hosséré Garba xenoliths. The M1 site volume (V(M1)) of these minerals show small variations or are virtually constant (Figure 3).

This is due to the $\mathrm{Al}^{\mathrm{IV}}$ and $\mathrm{R}^{3+}\left(\mathrm{Al}^{\mathrm{VI}}, \mathrm{Fe}^{3+}, \mathrm{Cr}\right.$ and $\mathrm{Ti}^{4+}$ ) relationship. The constant value of the volumes $\mathrm{V}(\mathrm{Cell})$ and V(M1) (see Table 2) for clinopyroxene compositions, indicates the similar pressures [26] in the spinelbearing lherzolite xenoliths from Hosséré Garba. V(Cell) and V(M1) relationships are more sensitive than the only chemical composition, to estimate the equilibration pressure of clinopyroxene [27].

Orthopyroxene (Table 3) with the compositions of Mg-enstatite (Mg\# = 90.6 - 92.4; $\mathrm{En}_{88.7-89.4} \mathrm{Wo}_{1.2-1.5} \mathrm{Fs}_{10.1-9.1}$ ) have been analyzed in the lherzolite xenoliths from Hosséré Garba. These crystals are characterized by the low $\mathrm{TiO}_{2}(0.05 \mathrm{wt} \%-0.14 \mathrm{wt} \%)$ and $\mathrm{Cr}_{2} \mathrm{O}_{3}(0.28 \mathrm{wt} \%-0.33 \mathrm{wt} \%)$ contents.

\subsection{Spinel}

Spinel crystals display homogenous compositions, with Mg\# and Cr\# ranging from 81.1 to 81.9 and from 10.6 to 10.8 respectively (Figure 4$)$.

$\mathrm{TiO}_{2}$ contents are low (0.11 wt $\%-0.13 \mathrm{wt} \%$ ) and those of $\mathrm{Al}_{2} \mathrm{O}_{3}$ are high (up to $57.8 \mathrm{wt} \%$ ). $\mathrm{The} \mathrm{Cr}_{2} \mathrm{O}_{3}$ contents vary between $10.26 \mathrm{wt} \%$ and $10.41 \mathrm{wt} \%$ (Table 4 ).

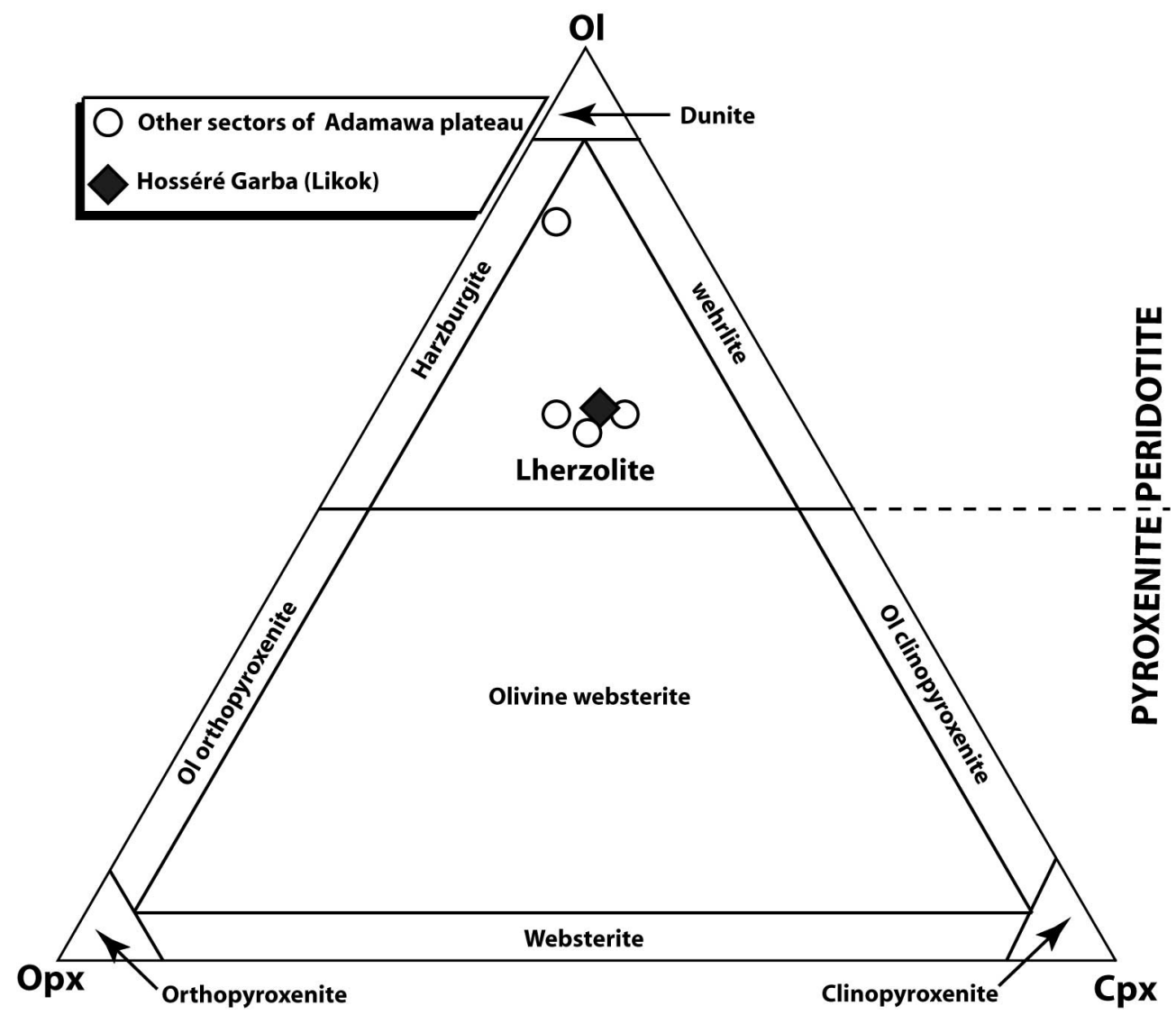

Figure 2. Classification diagram of ultramafic rocks (Streckeisen 1976) on the basis of the modal compositions, used for the nomenclature of Hosséré Garbe ultramafic xenolith types. 
Table 2. Clinopyroxene compositions (wt\% and a.p.f.u. on the basis of 6 oxygens) and elemental cation partition among T, M1 and M2 sites.

\begin{tabular}{|c|c|c|c|c|c|c|c|c|}
\hline $\mathrm{SiO}_{2}(\mathrm{wt} \%)$ & 51.88 & 51.99 & 52.47 & 51.76 & 52.25 & 51.85 & 51.97 & 52.44 \\
\hline $\mathrm{TiO}_{2}$ & 0.51 & 0.46 & 0.42 & 0.54 & 0.52 & 0.46 & 0.42 & 0.52 \\
\hline $\mathrm{Al}_{2} \mathrm{O}_{3}$ & 6.70 & 6.53 & 6.56 & 6.71 & 6.50 & 6.67 & 6.65 & 6.85 \\
\hline $\mathrm{Cr}_{2} \mathrm{O}_{3}$ & 0.78 & 0.73 & 0.74 & 0.75 & 0.67 & 0.77 & 0.75 & 0.72 \\
\hline $\mathrm{Fe}_{2} \mathrm{O}_{3}$ & 0.00 & 0.00 & 0.00 & 0.00 & 0.00 & 0.00 & 0.00 & 0.00 \\
\hline $\mathrm{MnO}$ & 0.10 & 0.10 & 0.14 & 0.13 & 0.09 & 0.10 & 0.11 & 0.08 \\
\hline $\mathrm{MgO}$ & 15.21 & 15.50 & 15.54 & 15.47 & 15.39 & 15.45 & 15.39 & 15.35 \\
\hline $\mathrm{CaO}$ & 20.76 & 20.26 & 20.55 & 20.26 & 20.52 & 20.51 & 20.33 & 20.55 \\
\hline $\mathrm{Na}_{2} \mathrm{O}$ & 1.64 & 1.61 & 1.70 & 1.72 & 1.75 & 1.70 & 1.57 & 1.73 \\
\hline Sum & 100.45 & 100.07 & 100.92 & 100.29 & 100.63 & 100.53 & 100.01 & 101.20 \\
\hline $\mathrm{Fe}_{2} \mathrm{O}_{3}$ (calc.) & 1.88 & 1.47 & 1.76 & 2.23 & 1.93 & 2.40 & 1.20 & 1.58 \\
\hline $\mathrm{FeO}$ (calc.) & 0.96 & 1.41 & 1.04 & 0.72 & 1.01 & 0.61 & 1.61 & 1.36 \\
\hline Sum (calc.) & 100.45 & 100.07 & 100.92 & 100.29 & 100.63 & 100.53 & 100.01 & 101.20 \\
\hline \multicolumn{9}{|l|}{ T-site } \\
\hline Si (a.p.f.u.) & 1.866 & 1.875 & 1.875 & 1.862 & 1.874 & 1.862 & 1.875 & 1.871 \\
\hline $\mathrm{Al}^{\mathrm{iv}}$ & 0.134 & 0.125 & 0.125 & 0.138 & 0.126 & 0.138 & 0.125 & 0.129 \\
\hline Sum & 2.000 & 2.000 & 2.000 & 2.000 & 2.000 & 2.000 & 2.000 & 2.000 \\
\hline \multicolumn{9}{|l|}{ M1-site } \\
\hline $\mathrm{Mg}$ & 0.737 & 0.737 & 0.741 & 0.738 & 0.739 & 0.740 & 0.733 & 0.728 \\
\hline $\mathrm{Fe}^{2+}$ & 0.029 & 0.039 & 0.028 & 0.020 & 0.027 & 0.017 & 0.045 & 0.037 \\
\hline $\mathrm{Al}^{\mathrm{vi}}$ & 0.150 & 0.152 & 0.152 & 0.147 & 0.149 & 0.145 & 0.158 & 0.159 \\
\hline $\mathrm{Fe}^{3+}$ & 0.047 & 0.039 & 0.047 & 0.060 & 0.052 & 0.065 & 0.032 & 0.043 \\
\hline $\mathrm{Ti}$ & 0.014 & 0.012 & 0.011 & 0.014 & 0.014 & 0.013 & 0.011 & 0.014 \\
\hline $\mathrm{Cr}$ & 0.022 & 0.021 & 0.021 & 0.021 & 0.019 & 0.022 & 0.021 & 0.020 \\
\hline Sum & 1.000 & 1.000 & 1.000 & 1.000 & 1.000 & 1.000 & 1.000 & 1.000 \\
\hline \multicolumn{9}{|l|}{ M2-site } \\
\hline $\mathrm{Ca}$ & 0.800 & 0.783 & 0.787 & 0.781 & 0.788 & 0.789 & 0.786 & 0.785 \\
\hline $\mathrm{Na}$ & 0.115 & 0.112 & 0.118 & 0.120 & 0.122 & 0.119 & 0.110 & 0.120 \\
\hline $\mathrm{Mg}$ & 0.079 & 0.097 & 0.087 & 0.092 & 0.084 & 0.087 & 0.095 & 0.088 \\
\hline $\mathrm{Fe}^{2+}$ & 0.003 & 0.005 & 0.003 & 0.002 & 0.003 & 0.002 & 0.006 & 0.004 \\
\hline $\mathrm{Mn}$ & 0.003 & 0.003 & 0.004 & 0.004 & 0.003 & 0.003 & 0.003 & 0.002 \\
\hline Sum & 1.000 & 1.000 & 1.000 & 1.000 & 1.000 & 1.000 & 1.000 & 1.000 \\
\hline V(cell) & 437.66 & 437.48 & 437.42 & 437.38 & 437.48 & 437.48 & 437.53 & 437.48 \\
\hline V(M1) & 11.39 & 11.40 & 11.39 & 11.39 & 11.39 & 11.39 & 11.39 & 11.37 \\
\hline $\mathrm{Al}^{\mathrm{VI}} / \mathrm{Al}^{\mathrm{IV}}$ & 1.1 & 1.2 & 1.2 & 1.1 & 1.2 & 1.0 & 1.3 & 1.2 \\
\hline Mg\# & 96.6 & 95.2 & 96.4 & 97.5 & 96.5 & 97.8 & 94.4 & 95.3 \\
\hline $\mathrm{Cr} \#$ & 7.2 & 7.0 & 7.0 & 7.0 & 6.5 & 7.2 & 7.0 & 6.6 \\
\hline Wo (mol.\%) & 44.8 & 46.5 & 44.1 & 46.6 & 46.5 & 44.9 & 44.7 & 45.6 \\
\hline En & 37.6 & 38.5 & 41.0 & 38.7 & 39.2 & 39.0 & 38.5 & 38.0 \\
\hline Fs & 17.6 & 15.0 & 14.8 & 14.7 & 14.3 & 16.1 & 16.8 & 16.4 \\
\hline
\end{tabular}

$\mathrm{V}($ cell $)=11,864 * \mathrm{Fe}^{2+}{ }_{\mathrm{M} 1}+9.107 * \mathrm{Fe}^{3+}-18.375 * \mathrm{Al}_{\mathrm{M} 1}+11.794 * \mathrm{Ti}-1.4925 * \mathrm{Cr}+439.97 * \mathrm{Ca}+419.68 * \mathrm{Na}+431.72 * \mathrm{Mg}_{\mathrm{M} 2}+432.56 * \mathrm{Fe} 2++$ $428.03 * \mathrm{Mn}-28.652 *\left(\mathrm{Mg}_{\mathrm{M} 2}\right)^{2}-12.741 *\left(\mathrm{Fe}^{2+}{ }_{\mathrm{M} 2}\right)^{2}$ and $\mathrm{V}(\mathrm{M} 1)=-0.3085 * \mathrm{Al}_{\mathrm{T}}+0.8130 * \mathrm{Fe}^{2+}{ }_{\mathrm{M} 1}-0.4173 * \mathrm{Fe}^{3+}-2.029 * \mathrm{Al} \mathrm{M}_{1}-1.0864 * \mathrm{Ti}-$ $0.8001 * \mathrm{Cr}+11.931 * \mathrm{Ca}+11.288 * \mathrm{Na}+11.432 * \mathrm{Mg}_{\mathrm{M} 2}+11.885 * \mathrm{Fe}^{2+}{ }_{\mathrm{M} 2}+12.038 * \mathrm{Mn}+2.4335 *\left(\mathrm{Mg}_{\mathrm{M} 2}\right)^{2}-1.1661 *\left(\mathrm{Fe}^{2+}{ }_{\mathrm{M} 2}\right)^{2}$ based on the papers of Nimis (1995) and Nimis and Ulmer (1998). 


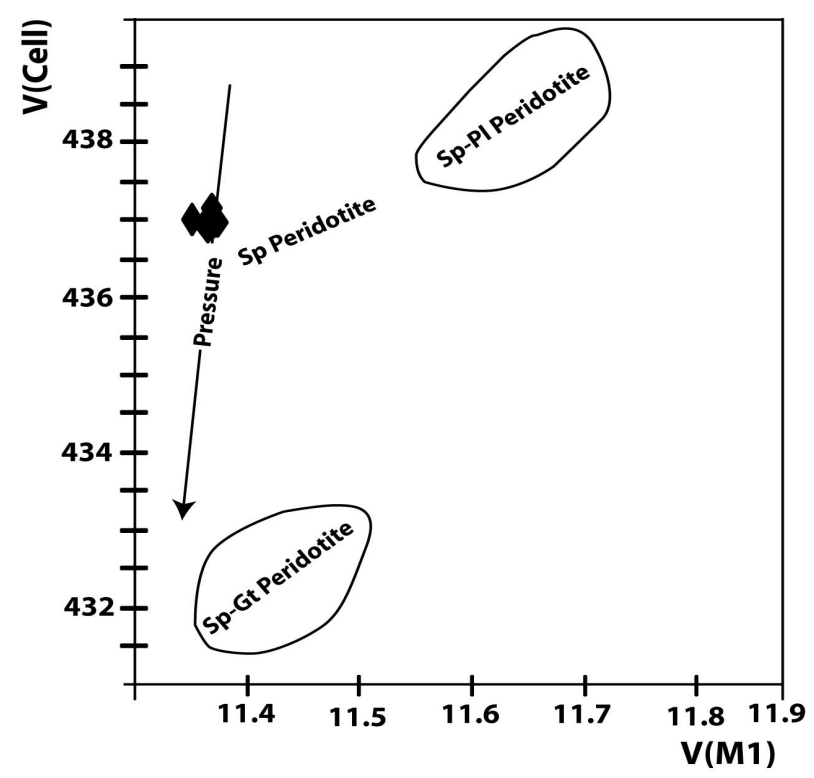

Figure 3. V(M1) vs. V(cell) diagram for clinopyroxene. The fields for clinopyroxene crystals from spinel-garnet (Sp-Gt) peridotite and spinel-plagioclase $(\mathrm{Sp}-\mathrm{Pl})$ peridotite are presented (Nimis, 1995).

Table 3. Orthopyroxene compositions (wt\% and a.p.f.u. on the basis of oxygens).

\begin{tabular}{|c|c|c|c|c|c|c|c|c|}
\hline $\mathrm{SiO}_{2}(\mathrm{wt} \%)$ & 54.90 & 54.96 & 55.53 & 55.03 & 55.61 & 55.56 & 55.34 & 55.32 \\
\hline $\mathrm{TiO}_{2}$ & 0.05 & 0.13 & 0.19 & 0.05 & 0.14 & 0.14 & 0.11 & 0.14 \\
\hline $\mathrm{Al}_{2} \mathrm{O}_{3}$ & 4.45 & 4.44 & 4.30 & 4.35 & 4.32 & 4.48 & 4.38 & 4.51 \\
\hline $\mathrm{Cr}_{2} \mathrm{O}_{3}$ & 0.28 & 0.31 & 0.28 & 0.32 & 0.26 & 0.32 & 0.28 & 0.33 \\
\hline $\mathrm{FeOt}$ & 6.04 & 6.40 & 6.02 & 6.23 & 6.12 & 6.12 & 6.06 & 6.25 \\
\hline $\mathrm{MnO}$ & 0.13 & 0.13 & 0.14 & 0.10 & 0.13 & 0.12 & 0.14 & 0.19 \\
\hline MgO & 33.15 & 32.99 & 33.16 & 33.39 & 32.97 & 33.07 & 33.27 & 33.53 \\
\hline $\mathrm{CaO}$ & 0.79 & 0.74 & 0.83 & 0.77 & 0.71 & 0.79 & 0.64 & 0.76 \\
\hline $\mathrm{Na}_{2} \mathrm{O}$ & 0.08 & 0.08 & 0.12 & 0.09 & 0.16 & 0.11 & 0.08 & 0.09 \\
\hline $\mathrm{K}_{2} \mathrm{O}$ & 0.00 & 0.01 & 0.02 & 0.02 & 0.01 & 0.00 & 0.04 & 0.00 \\
\hline Sum & 99.96 & 100.24 & 100.66 & 100.46 & 100.46 & 100.75 & 100.46 & 101.27 \\
\hline $\mathrm{Fe}_{2} \mathrm{O}_{3}$ (calc.) & 1.09 & 0.97 & 0.42 & 1.63 & 0.07 & 0.18 & 0.61 & 1.49 \\
\hline FeO (calc.) & 5.06 & 5.52 & 5.65 & 4.76 & 6.06 & 5.96 & 5.51 & 4.91 \\
\hline Sum (calc.) & 99.97 & 100.27 & 100.62 & 100.51 & 100.42 & 100.74 & 100.41 & 101.28 \\
\hline Si (a.p.f.u.) & 1.893 & 1.893 & 1.904 & 1.889 & 1.910 & 1.903 & 1.901 & 1.885 \\
\hline $\mathrm{Al}^{\mathrm{iv}}$ & 0.107 & 0.107 & 0.096 & 0.111 & 0.090 & 0.097 & 0.099 & 0.115 \\
\hline $\mathrm{Al}^{\mathrm{vi}}$ & 0.074 & 0.073 & 0.078 & 0.065 & 0.085 & 0.084 & 0.078 & 0.067 \\
\hline $\mathrm{Ti}$ & 0.001 & 0.003 & 0.005 & 0.001 & 0.004 & 0.004 & 0.003 & 0.003 \\
\hline $\mathrm{Cr}$ & 0.008 & 0.008 & 0.008 & 0.009 & 0.007 & 0.009 & 0.008 & 0.009 \\
\hline $\mathrm{Fe}^{3+}$ & 0.028 & 0.024 & 0.009 & 0.040 & 0.001 & 0.004 & 0.013 & 0.038 \\
\hline $\mathrm{Fe}^{2+}$ & 0.146 & 0.160 & 0.164 & 0.138 & 0.175 & 0.171 & 0.162 & 0.140 \\
\hline Mn & 0.004 & 0.004 & 0.004 & 0.003 & 0.004 & 0.004 & 0.004 & 0.006 \\
\hline $\mathrm{Mg}$ & 1.704 & 1.694 & 1.695 & 1.709 & 1.688 & 1.689 & 1.704 & 1.704 \\
\hline $\mathrm{Ca}$ & 0.029 & 0.027 & 0.030 & 0.028 & 0.026 & 0.029 & 0.023 & 0.028 \\
\hline $\mathrm{Na}$ & 0.006 & 0.005 & 0.008 & 0.006 & 0.010 & 0.007 & 0.006 & 0.006 \\
\hline Mg\# & 92.1 & 91.4 & 91.2 & 92.5 & 90.6 & 90.8 & 91.3 & 92.4 \\
\hline Wo (mol.\%) & 1.5 & 1.4 & 1.6 & 1.5 & 1.4 & 1.5 & 1.2 & 1.5 \\
\hline En & 89.2 & 88.7 & 89.1 & 89.1 & 89.1 & 89.0 & 89.4 & 88.9 \\
\hline Fs & 9.3 & 9.8 & 9.3 & 9.5 & 9.5 & 9.4 & 9.4 & 9.6 \\
\hline
\end{tabular}




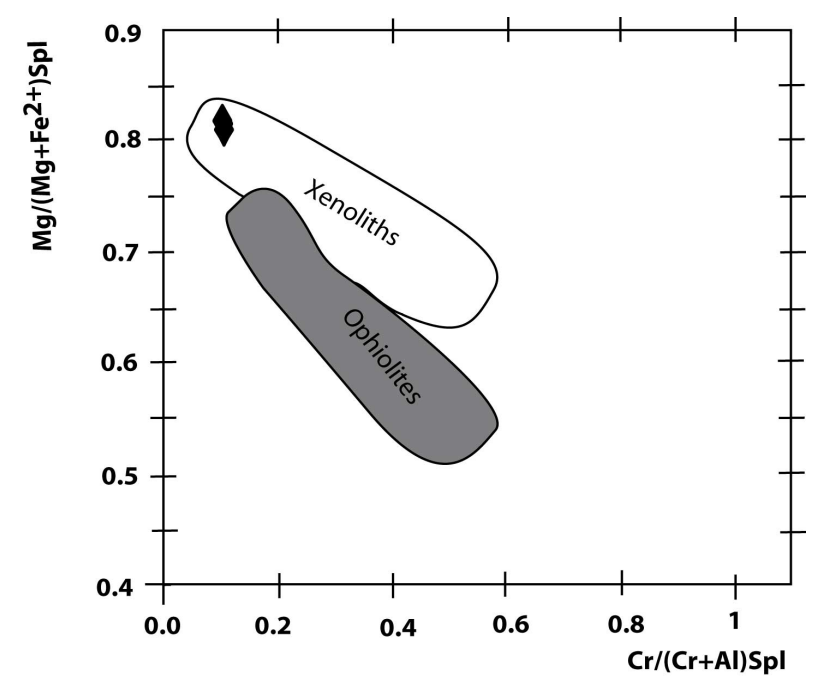

Figure 4. Mg\# vs. Cr\# diagram for spinels from Hosséré Garba. The domains of xenoliths and ophiolites are established respectively by Conticelli and Peccerillo (1990), and Cabanes and Mercier (1988).

Table 4. Spinel compositions (wt\% and a.p.f.u. on the basis of 32 oxygens).

\begin{tabular}{|c|c|c|c|c|}
\hline $\mathrm{SiO}_{2}(\mathrm{wt} \%)$ & 0.05 & 0.07 & 0.09 & 0.07 \\
\hline $\mathrm{TiO}_{2}$ & 0.12 & 0.13 & 0.13 & 0.11 \\
\hline $\mathrm{Al}_{2} \mathrm{O}_{3}$ & 57.82 & 57.84 & 57.50 & 57.40 \\
\hline $\mathrm{Cr}_{2} \mathrm{O}_{3}$ & 10.39 & 10.26 & 10.41 & 10.40 \\
\hline $\mathrm{FeOt}$ & 10.25 & 10.17 & 10.37 & 10.18 \\
\hline $\mathrm{MnO}$ & 0.13 & 0.08 & 0.09 & 0.06 \\
\hline $\mathrm{MgO}$ & 21.20 & 21.40 & 21.06 & 21.02 \\
\hline $\mathrm{CaO}$ & 0.00 & 0.00 & 0.00 & 0.00 \\
\hline $\mathrm{NiO}$ & 0.36 & 0.35 & 0.29 & 0.33 \\
\hline $\mathrm{V}_{2} \mathrm{O}_{5}$ & 0.00 & 0.05 & 0.01 & 0.00 \\
\hline Sum & 100.31 & 100.35 & 99.94 & 99.58 \\
\hline $\mathrm{Fe}_{2} \mathrm{O}_{3}$ (calc) & 1.88 & 1.91 & 1.77 & 1.71 \\
\hline $\mathrm{FeO}$ (calc) & 8.55 & 8.45 & 8.78 & 8.64 \\
\hline Sum (calc.) & 100.50 & 100.54 & 100.12 & 99.75 \\
\hline Si (a.p.f.u.) & 0.010 & 0.014 & 0.018 & 0.015 \\
\hline $\mathrm{Ti}$ & 0.018 & 0.021 & 0.019 & 0.017 \\
\hline $\mathrm{Al}$ & 13.971 & 13.954 & 13.953 & 13.971 \\
\hline $\mathrm{Cr}$ & 1.684 & 1.661 & 1.694 & 1.698 \\
\hline $\mathrm{Fe}^{3+}$ & 0.290 & 0.295 & 0.275 & 0.266 \\
\hline $\mathrm{Fe}^{2+}$ & 1.466 & 1.447 & 1.511 & 1.492 \\
\hline Mn & 0.022 & 0.014 & 0.016 & 0.011 \\
\hline $\mathrm{Mg}$ & 6.479 & 6.530 & 6.464 & 6.473 \\
\hline $\mathrm{Ca}$ & 0.001 & 0.000 & 0.000 & 0.001 \\
\hline $\mathrm{Na}$ & 0.000 & 0.000 & 0.000 & 0.000 \\
\hline $\mathrm{Ni}$ & 0.059 & 0.058 & 0.048 & 0.055 \\
\hline $\mathrm{V}_{2} \mathrm{O}_{5}$ & 0.000 & 0.007 & 0.001 & 0.000 \\
\hline Mg\# & 81.5 & 81.9 & 81.1 & 81.3 \\
\hline $\mathrm{Cr} \#$ & 10.8 & 10.6 & 10.8 & 10.8 \\
\hline
\end{tabular}




\section{Discussion}

\subsection{Geothermobarometry}

Using the orthopyroxene-clinopyroxene geothermometry of [28], equilibrium temperature of $\sim 905^{\circ} \mathrm{C}$ has been estimated for the Hosséré Garba spinel-bearing lherzolite xenoliths. Applying the geothermometer of [29], based on the solubility of $\mathrm{Al}_{2} \mathrm{O}_{3}$ in orthopyroxene and spinel, the temperature expression calibrated at the pressure of $1.5 \mathrm{GPa}$ in a natural spinel lherzolite system, gives the equilibrium temperatures of Hosséré Garba spinel-bearing lherzolite xenoliths of $1215^{\circ} \mathrm{C}-1245^{\circ} \mathrm{C}$.

The lack of plagioclase or gamet in Iherzolites and the fact that the lherzolite xenoliths have reached a high degree of internal chemical equilibrium, indicate that equilibration took place at pressures ranging between 0.7 and $1.1 \mathrm{GPa}(25$ - $36 \mathrm{~km})$. Hosséré Garba xenoliths have probably been sampled by the host-basalt in the upper mantle. At depths of $25-36 \mathrm{~km}$, the calculated temperatures are about $200^{\circ} \mathrm{C}$ above those of the oceanic geotherm of [30].

These equilibrium temperatures of spinel-bearing lherzolite xenoliths from Hosséré Garba fall more or less in the similar range as equilibrium temperatures of other lherzolite xenoliths along the Cameroon Volcanic Line and the Adamawa Plateau [7]-[23].

A maximum pressure can be calculated from the composition of spinel [31] or established with the clinopyroxene crystal chemistry data to determine the variability of the pressure during the partial melting. Hosséré Garba mantle xenoliths as those from Ngao Voglar [4] are spinel peridotites, containing neither plagioclase nor garnet, and were derived from the spinel stability field in the mantle, which lies in a pressure range of $\sim 0.8$ to $\sim 2$ GPa [32]-[34]. These estimated pressures can be associated to the depths ranging between 30 and $60 \mathrm{~km}$ as reported for the other spinel lherzolite xenoliths [35]-[40].

\subsection{Spinel-Bearing lherzolite Xenoliths Origin}

The refractory elements as $\mathrm{Cr}$ are enriched in the residue, as demonstrated for the $\mathrm{Cr}$-rich clinopyroxene from Hosséré Garbé xenoliths. Thus, the studied spinel-bearing lherzolite xenoliths, characterized by the presence of Cr-diopside, represent probably portions of the upper mantle [41].

However, the compositions of olivine and spinel are strongly dependent on the degree of melting, a feature characterized by a nearly constant values of $(\mathrm{Mg} \#)_{\mathrm{Ol}},(\mathrm{Mg} \#)_{\mathrm{Sp}}$, and $(\mathrm{Cr} \#)_{\mathrm{Sp}}$. Based on these data, the xenoliths from Hosséré Garba represent a residual sequence issued from partial melting of a mantle source. Experiments have shown that the composition of solid solutions, such as olivine, is very sensitive to temperature changes, and olivine could therefore evolve towards refractory compositions during the partial melting. So, an extraction of the melt could leave a residue depleted in highly incompatible elements (e.g. $\mathrm{Na}, \mathrm{Al}, \mathrm{K}$, and $\mathrm{Ti}$ ) and enriched in $\mathrm{Cr}$ and $\mathrm{Ni}$ relative to the most primitive mantle [21]. The range of Ni contents of olivine of lherzolites from Hosséré Garba confirms that they are residues of melting. It appears that high contents of Ni (2500 - 4100 ppm) in olivine suggest that xenoliths from Hosséré Garba could derive from a low degree of melting ( $30 \%)$ of a relatively homogeneous mantle source. Thus, the model of [41] for portions of the earth's upper mantle appears appropriate for the origin of the Hosséré Garba spinel-bearing lherzolite xenoliths.

\section{Conclusion}

The spinel-bearing lherzolite xenoliths from Hosséré Garba represent a residual sequence issued from partial melting of a mantle source. The compositions of their silicate minerals are typical of equilibrated Mg-rich olivine, Al-rich enstatite and Cr-diopside in the upper mantle. Similar compositions have been recorded in minerals of ultramafic xenoliths from other ultramafic xenoliths domains of the Cameroon Volcanic Line and the Adamawa Plateau. Thus, ultramafic xenoliths from Hosséré Garba represent peridotites sampled from lithospheric mantle and hosted in the basaltic lava flows.

\section{References}

[1] Menzies, M.A., Halliday, A.N., Palacz, Z., Hunter, R.H., Upton, B.G.J., Aspen, P. and Hawkesworth, C.J. (1987) Evidence from Mantle Xenoliths for an Enriched Lithospheric Keel under the Outer Hebrides. Nature, 325, 44-47. http://dx.doi.org/10.1038/325044a0

[2] Frey, F.A. and Prinz, M. (1978) Ultramafic Inclusions from San Carlos, Arizona: Petrologic and Geochemical Data 
Bearing on Their Protogenesis. Earth and Planetary Science Letters, 38, 129-175. http://dx.doi.org/10.1016/0012-821X(78)90130-9

[3] Ngounouno, I., Dagwai, N., Kamgang, P. and Deruelle, B. (2008) Petrology of Spinel Lherzolite Xenoliths in Alkali Basalts from Liri, South of the Kapsiki Plateau (Northernmost Cameroon Hot Line). Journal of Cutaneous and Aesthetic Surgery, 8, 31-42.

[4] Nkouandou, O.F. and Temdjim, R. (2011) Petrology of Spinel Lherzolite Xenoliths and Host Basaltic Lava from Ngao Voglar Volcano, Adamawa Massif (Cameroon Volcanic Line, West Africa): Equilibrium Conditions and Mantle Characteristics. Journal of Geosciences, 56, 375-387.

[5] Teitchou, S.F., Van Schmus, W.R., Penaye, J. and Michard, A. (2001) New U-Pb and SmNd Data from North-Central Cameroon and Its Bearing on the Pre-Pan-African History of Central Africa. Precambrian Research, 108, 45-53. http://dx.doi.org/10.1016/S0301-9268(00)00149-2

[6] Girod, M., Dautria, J.-M. and Balle, S.D. (1984) Estimation de la profondeur du manteau du Moho sous le massif volcanique de l'Adamaoua (Cameroun) à partir de l'étude d'enclaves de lherzolite. C. R. Acad. Sci. Paris 2, 298, 699-704.

[7] Dautria, J.M. and Girod, M. (1986) Les enclaves de lherzolite à spinelle et plagioclase du volcan de Dibi (Adamaoua, Cameroun): Des témoins du manteau anormal. Bull. Minéral, 109, 275-286

[8] Temdjim, R. (2005) Contribution à la connaissance du manteau supérieur du Cameroun au travers de l'étude des enclaves ultrabasiques et basiques par les volcans de Youkou (Adamaoua) et de Nyos (Ligne du Cameruon). Thèse de Doctorat d'Etat, Université de Yaoundé 1, 339 p.

[9] Moreau, C., Regnoult, J.-M., Déruelle, B. and Robineau, B. (1987) A New Tectonic Model for the Cameroon Line, Central Africa. Tectonophysics, 139, 317-334. http://dx.doi.org/10.1016/0040-1951(87)90206-X

[10] Toteu S.F., Van Schmus, R.W., Penaye, J. and Nyobe, J.B. (1994) U-Pb and Sm-Nd Evidence for Eburnian and Pan-African High-Grade Metamorphism in Cratonic Rocks of Southern Cameroon. Precambrian Research, 67, 321347. http://dx.doi.org/10.1016/0301-9268(94)90014-0

[11] Penaye, J., Toteu, S.F., Tchameni, R., Van Schmus, W.R., Tchakounte, J., Ganwa, A., Minyem, D. and Nsifa, E.N. (2004) The 2.1 Ga West Central African Belt in Cameroon: Extension and Evolution. Journal of African Earth Sciences, 39, 159-164. http://dx.doi.org/10.1016/j.jafrearsci.2004.07.053

[12] Lasserre, M. and Soba, D. (1979) Migmatisation d'âge panafricain au sein des formations camerounaises appartenant à la zone mobile d'Afrique centrale. Comptes Rendus sommaires Société Géologique de France, 2, 64-68.

[13] Castaing, C., Feybesse, J.L., Thieblemont, D., Triboulet, C. and Chevremont, P. (1994) Palaeogeographical Reconstructions of the Pan-African/Brasiliano Orogen: Closure of an Oceanic Domain or Intercontinental Convergence between Major Blocks? Precambrian Research, 67, 327-344. http://dx.doi.org/10.1016/j.jafrearsci.2004.07.053

[14] Tchameni, R., Pouclet, A., Penaye, J., Ganwa, A.A. and Toteu, S.F. (2006) Petrography and Geochemistry of the Ngaoundéré Pan-African Granitoids in Central North Cameroon: Implications for Their Sources and Geological Setting. Journal of African Earth Sciences, 44, 511-529. http://dx.doi.org/10.1016/j.jafrearsci.2005.11.017

[15] Nono, A., Déruelle, B., Demaiffe, S.D. and Kambou, R. (1994) Tchabal Nganha Volcano in Adamawa (Cameroon): Petrology of a Continental Alkaline Lava Series. Journal of Volcanology and Geothermal Research, 60, 147-178. http://dx.doi.org/10.1016/0377-0273(94)90066-3

[16] Itiga, Z., Chakam-Tagheu, P.-J., Wochoko, P., Wandji, P., Bardintzeff, J.M. and Bellon, H. (2004) La Ligne du Cameroun: Volcanologie et géochronologie de trois régions (Mont Manengouba, Plaine de Noun et Tchabal Gangdaba). Géochronique, 91, 13-16.

[17] Temdjim, R., Boivin, P., Chazot, G., Robin, C. and Roulleau, E. (2004) L’hétérogénéité du manteau supérieur à l'aplomb du volcan de Nyos (Cameroun) révélée par les enclaves ultrabasiques. Comptes Rendus Geoscience, 336, 1239-1244. http://dx.doi.org/10.1016/j.crte.2004.07.005

[18] Nkouandou, O.F., Ngounouno, I., Déruelle, B., Ohnenstetterd, D., Montigny, R. and Demaiffe, D. (2008) Petrology of the Mio-Pliocene Volcanism to the North and East of Ngaoundéré (Adamawa, Cameroon). Comptes Rendus Geoscience, 340, 28-37. http://dx.doi.org/10.1016/j.crte.2007.10.012

[19] Mbowou, G.B. (2010) Pétrologie du volcanisme bimodal du Djinga Tadorgal (Adamaoua, Cameroun). Rev Cames, 11, 36-42.

[20] Harte, B. (1977) Rock Nomenclature with Particular Relation to Deformation and Recrystallisation Textures in Olivine-Bearing Xenoliths. Journal of Geology, 85, 279-288. http://dx.doi.org/10.1016/j.crte.2007.10.012

[21] Irving, A.J. (1980) Petrology and Geochemistry of Composite Ultramafic Xenoliths in Alkalic Basalts and Implications for Magmatic Processes in the Mantle. American Journal of Science, 280A, 389-426.

[22] Lee, D.C., Halliday, A.N., Davies, G.R., Essene, E.J., Fitton, G.J. and Temdjim, R. (1996) Melt Enrichment of Shallow Depleted Mantle: A Detailed Petrological, Trace Element and Isotopic Study of Mantle-Derived Xenoliths and Megacrysts from the Cameroon Line. Journal of Petrology, 37, 415-441. http://dx.doi.org/10.1016/j.crte.2007.10.012 
[23] Brey, G.P. and Kohler, T. (1990) Geothermobarometry in Four-Phase Lherzolites II, New Thermobarometers, and Practical Assessment of Existing Their Barometers. Journal of Petrology, 31, 1353-1378. http://dx.doi.org/10.1016/j.crte.2007.10.012

[24] Morimoto, N. (1989) Nomenclature of Pyroxenes. Can. Mineral., 27, 143-154.

[25] Dal Negro, A., Carbonin, S., Domeneghetti, C., Molin, G.M., Cundari, A. and Piccirillo, E.M. (1984) Crystal Chemistry and Evolution of the Clinopyroxene in a Suite of High Pressure Ultramafic Nodules from the Newer Volcanics of Victoria, Australia. Contributions to Mineralogy and Petrology, 86, 221-229.

[26] Princivalle, F., Salviulo, G., Fabro, C. and Demarchi, G. (1994) Inter- and Intra-Crystalline Temperature and Pressure Estimates on Pyroxenes from NE Brazil Mantle Xenoliths. Contributions to Mineralogy and Petrology, 116, 1-6. http://dx.doi.org/10.1007/BF00310685

[27] Wells, P.R.A. (1977) Pyroxene Thermometry in Sample and Complex System. Contributions to Mineralogy and Petrology, 62, 129-139. http://dx.doi.org/10.1007/BF00310685

[28] Bertrand, P., Sotin, C., Gaulier, J.M. and Mercier, J.C.C. (1987) La solubilité de l'aluminium dans l'orthopyroxène. Inversion globale des données expérimentales du systeme $\mathrm{MgO}-\mathrm{Al}_{2} \mathrm{O}_{3}-\mathrm{SiO}_{2}$. Bulletin de la Societé Géologique de France, 8, 821-832.

[29] Clark Jr., S.J. and Ringwood, A.E. (1964) Density Distribution and Constitution of the Mantle. Reviews of Geophysics, 2, 35-88. http://dx.doi.org/10.1029/RG002i001p00035

[30] O’neill, H.S.C. (1981) The Transition between Spinel Lherzolite and Garnet Lherzolite, and Its Use as a Geobarometer. Contributions to Mineralogy and Petrology, 77, 185-194. http://dx.doi.org/10.1007/BF00636522

[31] Green, D.H. and Hibberson, W. (1970) The Instability of Plagioclase in Peridotite at High Pressure. Lithos, 3, $209-221$. http://dx.doi.org/10.1016/0024-4937(70)90074-5

[32] Green, D.H. (1973) Condition of Melting of Basaltic Magma from Grenat Peridotite. Earth and Planetary Science Letters, 17, 456-465. http://dx.doi.org/10.1016/0012-821X(73)90214-8

[33] Gasparik, T. (1987) Orthopyroxene Thermobarometry in Simple and Complex Systems. Contributions to Mineralogy and Petrology, 96, 357-370. http://dx.doi.org/10.1007/BF00371254

[34] O’reilly, S.Y., Chen, D., Griffin, W. and Ryan, C.G. (1997) Minor Elements in Olivine from Spinel Lherzolite Xenoliths: Implications for Thermobarometry. Mineralogical Magazine, 61, 257-269. http://dx.doi.org/10.1180/minmag.1997.061.405.09

[35] Xu, X., O’reilly, S.Y., Griffin, W.L., Zhou, X.M. and Huang, X.L. (1998) The Nature of the Cenozoic Lithosphere at Nushan, Eastern China. In: Flower, M.F.J., Ed., Mantle Dynamics and Plate Interactions in East Asia, American Geophysical Union, Washington DC, 167-195. http://dx.doi.org/10.1029/GD027p0167

[36] Glaser, S.M., Foley, S.F. and Günther, D. (1999) Trace Element Compositions of Minerals in Garnet and Spinel Peridotite Xenoliths from the Vitim Volcanic field, Transbaikalia, Eastern Siberia. Lithos, 48, 263-285. http://dx.doi.org/10.1016/S0024-4937(99)00032-8

[37] Medaris Jr., G., Wang, H.F., Fournelle, J.H., Zimmer, J.H. and Jelinek, E. (1999) A Cautionary Tale of Spinel Peridotite Thermobarometry: An Example from Xenoliths of Kozákov Volcano, Czech Republic. Geolines, 9, 92-96.

[38] Christensen, N.I., Medaris Jr., L.G. and Wang, H.F. (2001) Depth Variation of Seismic Anisotropy and Petrology in Central European Lithosphere: A Tectonothermal Synthesis from Spinel Lherzolites. Journal of Geophysical Research, 106, 645-661. http://dx.doi.org/10.1029/2000JB900333

[39] Foley, S.F., Andronikov, A.V., Jacob, D.E. and Melzer, S. (2006) Evidence from Antarctic Mantle Peridotite Xenoliths for Changes in Mineralogy, Geochemistry and Geothermal Gradients beneath a Developing Rift. Geochimica et Cosmochimica Acta, 70, 3096-3120.

[40] Green, D.H. and Ringwood, A.E. (1967) The Genesis of Basaltic Magmas. Contributions to Mineralogy and Petrology, 15, 103-190. http://dx.doi.org/10.1007/BF00372052

[41] Mysen, B.O. and Kushiro, I. (1977) Compositional Variations of Coexisting Phases with Degrees of Melting of Peridotte in the Upper Mantle. American Mineralogist, 62, 843-865. 
Scientific Research Publishing (SCIRP) is one of the largest Open Access journal publishers. It is currently publishing more than 200 open access, online, peer-reviewed journals covering a wide range of academic disciplines. SCIRP serves the worldwide academic communities and contributes to the progress and application of science with its publication.

Other selected journals from SCIRP are listed as below. Submit your manuscript to us via either submit@scirp.org or Online Submission Portal.
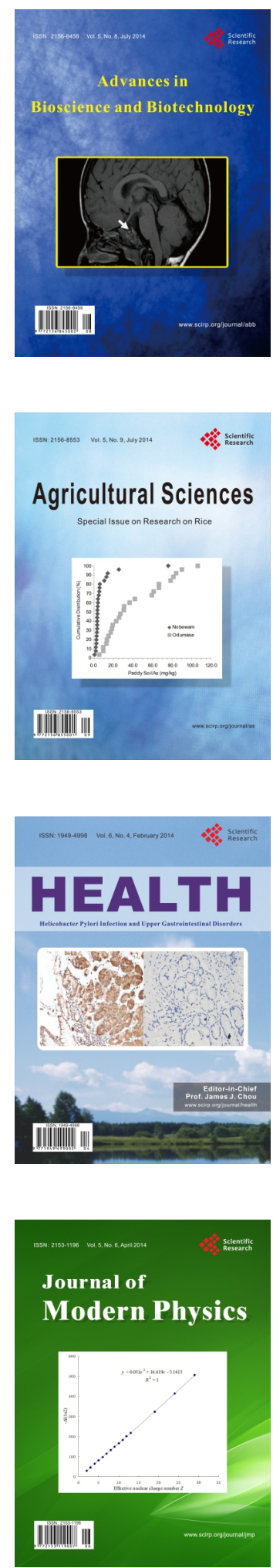
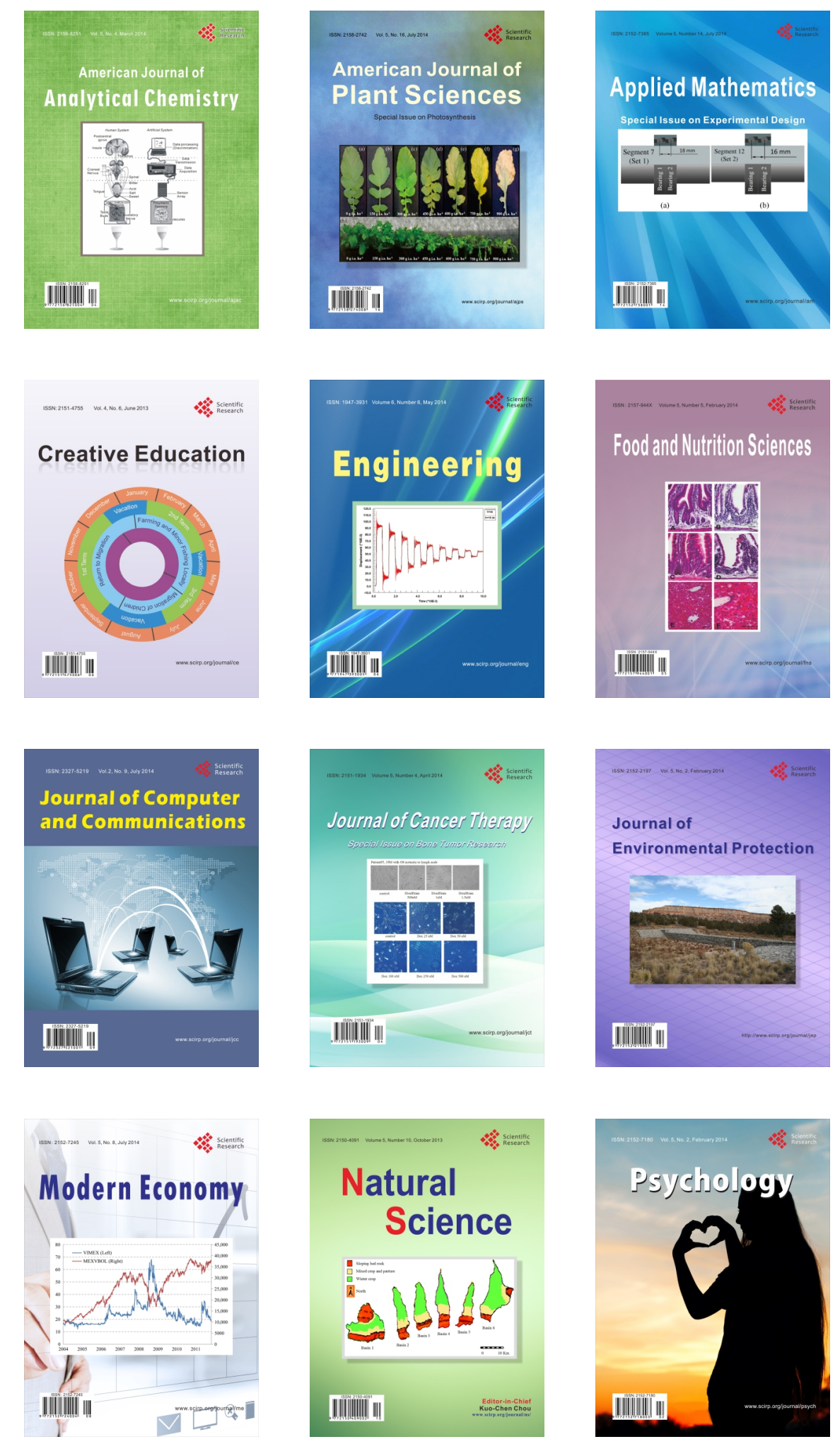